\title{
Effects of Reed (Phragmites communis) on Growth Performance, Carcass Characteristics, and Meat Quality in Hanwoo Steers
}

\author{
Sang Min Lee', Sun Sik Chang', Ki Yong Chung', Hyeong Cheol Kim', Sun Ho Choi', \\ Ha Yeon Jeong', Boh Suk Yang', Sung Sill Lee and Young Moo Cho'* \\ ${ }^{1}$ National Institute of Animal Science, RDA, Pyeongchang 232-950, Korea \\ ${ }^{2}$ Division of Applied Life Science, Graduate School Gyeangsang National Univerity, Jinju 660-701, Korea
}

Received August 27, 2012 /Revised October 21, 2012 /Accepted October 22, 2012

\begin{abstract}
This study investigated the effects of diet of different forages on growth performance and carcass characteristics of Hanwoo steers. Twenty-one Hanwoo steers were randomly allocated to three groups (fed hay, reed, and reed with rice straw) of seven steers each. Initial and final body weights of control, T1, and T2 groups were 125.5, 128.3, $128.3 \mathrm{~kg}$ and $697.4,614.6,706.7 \mathrm{~kg}$, respectively. Average daily gain tended to increase in controls $(0.70 \mathrm{~kg} / \mathrm{d})$ and the T2 group $(0.71 \mathrm{~kg} / \mathrm{d})$ but not as much in the T1 group $(0.60 \mathrm{~kg} / \mathrm{d})$; however, there was no significant difference. DMI was not significantly different among the treatment groups, but T1 was relatively lower than the other groups. For the yield traits, carcass weight was not significantly different between controls and the T2 group but was greater in the T2 group compared to the T1 group $(p<0.05)$. Back fat thickness and rib eye area were higher in controls and T2 compared to T1; yield grade (A:B:C, \%) was greater in T1 (43:57:0) compared to the other groups (control 0:71:29; T2 29:42:29). For the quality traits, fat color and texture were not significantly different among groups. However, meat color and maturity were significantly greater in T1 compared to T2 $(p<0.05)$. Marbling score and appearance rate of over 1st meat quality grade were greater in the control and T2 groups compared to the T1 group. Based on the results, growth performance, feed utilization, and carcass traits appeared to improve when roughage containing rice straw plus reed was offered. Therefore, reed is worth considering as a roughage source for fattening Hanwoo steers.
\end{abstract}

Key words : Reed, Hanwoo steers, growth performance, carcass, meat quality

\section{서 론}

최근 한우산업은 가축 악성질병의 발생과 FTA 추진에 따른 시장개방 확대로 쇠고기 수입의 증가와 바이오 에너지 생산에 따른 원료사료 가격의 상승 등으로 많은 어려움을 겪고 있다. 따라서 한우산업에 있어 가장 중요한 것은 생산비의 $40 ~ 50 \%$ 를 차지하는 사료비의 절감이라고 하여도 과언이 아닐 것이 다. 현재 우리나라 조사료 자급율은 약 $84 \%$ 수준이고[26], 반 추가축에 이용되는 양질 조사료의 대부분은 수입에 의존하고 있는 실정이다. 최근 우리나라에서 반추가축의 조사료 자원으 로 주로 이용되고 있는 볏짚은 소 사육두수 증가와 이로 인한 수요증가로 가격이 상승하고 있어 저렴한 조사료 자원의 확보 가 시급한 실정이다.

최근 축산업의 위기극복을 위한 방안으로 농산부산물(버섯 폐배지, 녹차 부산물 등), 식품 가공부산물(비지박, 맥주박 등) 및 야초류(억새, 갈대 등) 등의 대체 사료 개발을 통해 생산비 절감과 조사료 자원의 확보를 위한 연구가 수행되어 사료자원

*Corresponding author

Tel : +82-33-330-0612, Fax : +82-33-330-0660

E-mail : choymoo@korea.kr
으로 활용되고 있다. 그 중 야초류의 갈대(Phragmites commu$n i s)$ 는 우리나라 전역에 걸쳐 자생하는 여러해살이 식물로 어 린 순은 식용, 이삭은 빗자루, 털은 솜 대신 이용하였다[18]. 그리고 갈대의 여러 부위는 약재로 이용되기도 하였는데 이 뇨, 해열, 당뇨성 고지혈증 및 치매치료에도 효과가 우수하다 고 알려져 있다[10,30]. 사료자원으로서의 갈대는 적정 생육시 기[11,12,22]와 예취시기[13], 안전성[20] 및 이용실태와 지역별 갈대의 사료가치에 관한 연구가 수행되었고[31,32], 현재 우리 나라 전역에서 반추가축의 조사료 자원으로 이용되고 있다 [31,32]. 하지만 갈대는 예취시기별 영양성분의 차이가 크고 [32], 반추가축이 꺼려하는 알칼로이드 성분이 약간 함유되어 있어 사료 자원으로 이용하기 위한 가축의 기호성과 안전성에 대한 검증도 필요할 것으로 판단된다.

선행 연구에서는 사료가치 평가와 사료화를 위한 생산 연구 가 대부분이었고, 실질적인 사양실험을 통한 가축의 기호성, 영양소 이용율 및 도체와 육질특성 구명을 위한 연구는 전무 한 실정이다. 그러므로, 조사료 자원으로서 갈대의 사료적 가 치평가는 한우 비육우의 사양시험을 통해 검증 할 필요가 있 다. 따라서, 본 연구는 한우 거세 비육우에 갈대 급여가 발육과 사료섭취량 및 도체·육질에 미치는 영향을 구명하고자 수행하 
였다.

\section{재료 및 방법}

\section{공시동물 및 사양관리}

생후 약 6개월령(평균체중 $125.9 \pm 12.0 \mathrm{~kg}$ ) 한우 거세우 21두 를 공시하여, 국립축산과학원 한우시험장에서 처리구별 7 두 씩 군집사육하면서 24 개월간 사양시험을 수행하였다. 배합사 료는 1 일 급여량을 2 회 $(08: 00,16: 00)$ 균등분배하여 급여하였 고, 조사료는 자유채식토록 하였다. 물과 미네랄블록(린칼 $\mathrm{V}$ 부록, (주대한뉴팜) 항시 섭취할 수 있도록 하였고, 사료섭취량 은 매일, 체중은 매월 조사하였고, 체중에 따라 사료 급여량을 조절하였으며, 시험축 사양관리는 Table 1 을 기준으로 수행하 였다.

\section{시험사료}

공시동물에게 급여한 배합사료는 시판되는 성장단계별(육 성, 비육전·중기 및 후기) 비육우 전용 사료를 사용하였고, 조 사료는 국립축산과학원 한우시험장에서 생산된 혼합목건초 (강원도 대관령면)를, 볏짚은 강원도 지역에서 생산된 것을 구 입하였고, 갈대는 충청도 지역에서 출수기에 채취하여 반추가 축용으로 시판되는 것을 구입하여 사용하였다. 시험에 이용된 사료의 일반성분은 Table 2에 나타내었다.

\section{시험설계}

시험구 배치는 육성기에 건초급여 후 비육기에 볏짚을 급여한 관행 사양구(대조구), 갈대 급여구(T1), 볏짚+갈대 급여구(T2)로 3처리 7반복으로 완전임의 배치하여 수행하 였다.

\section{발육조사}

체중은 시험 개시일부터 종료 시까지 시험축사 내에 설치 된 우형기(CAS Korea, Newton HT-501A)를 이용하여 1개월 간격으로 오전 사료급여 전에 측정하였고, 증체량은 이전 체 중에서 측정된 값의 차로 구하였으며, 총 증체량의 평균값을 시험일수로 나누어 일당증체량을 구하였다. 사료섭취량은 매 일 오전 사료 급여 전 사조 내의 잔량을 조사한 후 전날 급여량 에서 뺀 값을 섭취량으로 계산하였다.

\section{도체조사 및 육질분석}

도체조사는 사양시험이 종료된 공시축을 국립축산과학원 축산생명환경부(경기도 수원시) 내 시험도축장에서 도축한 후, $0^{\circ} \mathrm{C}$ 에서 $18 \sim 24$ 시간 동안 도체를 현수시킨 후 육량판정요 인(도체중, 등지방두께, 배최장근단면적)과 육질판정요인(근 내지방도, 육색, 지방색, 조직감, 성숙도)을 소 도체등급판정기 준에 의거하여 축산물등급판정사가 평가하였다. 육질분석을

Table 1. Feeding management of experimental animals

\begin{tabular}{lcccc}
\hline \multirow{2}{*}{ Items } & \multicolumn{4}{c}{ Feeding periods (Month) } \\
\cline { 2 - 5 } & $6 \sim 11$ & $12 \sim 15$ & $16 \sim 21$ & $22 \sim 32$ \\
\hline Concentrate (BW, \%) & $1.5 \sim 1.6$ & $1.6 \sim 1.8$ & $1.8 \sim 1.9$ & Ad libitum \\
Forage & Hay & Rice straw & Ribitum straw & Rice straw \\
Control & Reed & Reed & Reed & Rice straw \\
T1 & Rice straw+Reed (5:5) & Rice straw+Reed (5:5) & Rice straw+Reed (5:5) & Rice straw \\
T2 (Ratio) & & & &
\end{tabular}

Table 2. Chemical composition of diets used in this experiment (DM basis, \%)

\begin{tabular}{|c|c|c|c|c|c|c|}
\hline \multirow{2}{*}{ Items } & \multicolumn{3}{|c|}{ Concentrate } & \multirow{2}{*}{ Hay } & \multirow{2}{*}{ Rice straw } & \multirow{2}{*}{ Reed } \\
\hline & Growing & Early fattening & Late fattening & & & \\
\hline $\mathrm{DM}^{1)}$ & 90.24 & 88.58 & 90.52 & 90.13 & 91.43 & 90.80 \\
\hline $\mathrm{CP}^{2)}$ & 16.42 & 15.04 & 14.08 & 15.87 & 4.39 & 6.61 \\
\hline $\mathrm{EE}^{3)}$ & 3.34 & 3.74 & 4.80 & 2.78 & 2.36 & 1.36 \\
\hline$C A^{4)}$ & 10.28 & 9.94 & 9.41 & 7.15 & 13.07 & 7.17 \\
\hline $\mathrm{NDF}^{5}$ & 31.67 & 31.97 & 28.05 & 76.29 & 70.21 & 61.11 \\
\hline $\mathrm{ADF}^{6)}$ & 12.07 & 12.02 & 11.10 & 40.15 & 38.13 & 38.29 \\
\hline $\mathrm{TDN}^{7)}$ & 68.00 & 71.00 & 72.00 & 53.00 & 44.00 & 45.00 \\
\hline
\end{tabular}

${ }^{1)}$ DM: Dry matter

${ }^{2)} \mathrm{CP}$ : Crude protein

${ }^{3)} \mathrm{EE}$ : Ether extract

${ }^{4)} \mathrm{CA}$ : Crude ash

${ }^{5)}$ NDF: Neutral detergent fiber

${ }^{6}$ ADF: Acid detergent fiber.

${ }^{77}$ TDN: Total Digestible Nutrients 
위한 시료는 도체 등급 판정을 받은 후 제 13 번째 늑골의 등심 부위와 제 12 번째 늑골의 등심부위 사이에서 일정량을 채취하 고 개체별로 냉장상태 $\left(0 \sim 5^{\circ} \mathrm{C}\right)$ 를 유지시켜 실험실로 운반한 다 음, 등심육의 수분, 조지방과 조단백질을 분석 하였으며[2], 육 색은 근육을 절단하여 공기 중에 30 분 정도 노출시킨 후 Chromameter (CR301, Minolta Co., Germany)로 명도(CIE L), 적색도 $(\mathrm{CIE} \quad \mathrm{a})$, 황색도 $(\mathrm{CIE} \quad \mathrm{b})$ 를 $\mathrm{CIE}$ (Commision Internationale de Leclairage) 값으로 3반복 측정하여 평균값 으로 계산하였다. Folch 등[16]의 방법으로 methanol:chloroform $(1: 2, v / v)$ 으로 지방을 추출하였으며 가수분해는 Morrison과 Smith[27]의 방법으로 분석하였다. 지방산 조성은 Gas Chromatography (Varian 3600, Varian, USA)를 사용하 여 분석하였으며 Gas Chromatography (GC) 조건은 silica capillary column (Omegawax 205, $30 \mathrm{~m} \times 0.32 \mathrm{~mm}$ I.D., $0.25 \mu \mathrm{m}$ film thickness)을 이용하였고 Injection port 온도는 $250^{\circ} \mathrm{C}$ 이었 으며 검출기 온도는 $260^{\circ} \mathrm{C}$ 로 유지하였다. 분석결과는 전체 피 크면적에 대한 비율(\%)로 계산하였다.

\section{통계처리}

본 시험에서 얻어진 모든 성적들은 SAS (Statistical Analysis System software version 9.2)를 이용하여 분산분석 및 처리구간 유의성 $(p \times 0.05)$ 을 검증하였다.

\section{결과 및 고찰}

\section{발육 및 사료섭취량}

한우 거세우의 체중 및 일당증체량은 Table 3에 나타내었 다. 시험 개시 체중은 처리구별(대조구, T1 및 T2)로 각각 $125.5,128.3$ 및 $128.3 \mathrm{~kg}$ 으로 차이가 없었으나 종료 시 체중에 서는 각각 697.4, 614.6 및 $706.7 \mathrm{~kg}$ 으로 $\mathrm{T} 1$ 처리구가 유의적인 차이는 없었지만 가장 낮았다. 또한 각 처리구별 육성기의 일 당증체량은 각각 $0.75,0.47$ 및 $0.52 \mathrm{~kg} /$ 일으로 대조구가 가장 높은 경향을 보였는데 육성기부터 비육중기까지의 일당증체
량 역시 대조구가 가장 높았다. 모든 처리구에 볏짚을 급여한 비육후기 일당증체량은 처리구별로 각각 $0.59,0.61$ 및 0.65 $\mathrm{kg} /$ 일으로 $\mathrm{T} 2$ 처리구가 가장 높았지만 처리구간에 통계적인 유의 차이는 없었다. 시험 전기간 평균 일당증체량은 $\mathrm{T} 2$ 처리 구가 $0.71 \mathrm{~kg} /$ 일으로 가장 높았고, T1처리구가 $0.60 \mathrm{~kg} /$ 일으 로 가장 낮았으나 역시 통계적인 유의차이는 인정되지 않았 다. 전체적인 발육성적은 갈대를 급여한 $\mathrm{T} 1$ 처리구가 다른 처 리구에 비해 낮은 경향을 보였다.

한우 거세우의 성장단계별 사료섭취량 및 사료요구율을 조 사한 결과는 Table 4 와 같다. 사료섭취량에 있어 비육 후기를 제외한 전기간에서 배합사료 급여량은 제한하였고 조사료는 자유채식토록 하였는데, 비육중기를 제외한 전기간 동안 대조 구에서 건물섭취량이 가장 많았고, 비육중기에는 T2 처리구가 가장 많이 섭취한 것으로 나타났다. 사료요구율은 시험개시 후 비육중기까지(생후6 21개월령) 대조구에서 향상된 결과를 나타내었고, 비육후기에는 $\mathrm{T} 2$ 처리구가 우수한 것으로 조사되 었다. 전기간 사료요구율은 볏짚과 갈대를 혼합 급여한 $\mathrm{T} 2$ 처 리구가 가장 우수한 것으로 나타났다.

육성기에서 대조구의 일당증체량이 가장 높은 것은 건초의 영양소 함량이 볏짚이나 갈대보다 우수하였기 때문인 것으로 판단되는데, White 등[34]은 볏짚 급여구 보다 목건초 급여구 에서 배합사료 이용효율이 향상되고, 조사료의 질이 낮을수록 일당증체량은 감소한다고 하였다[24]. 시험기간 동안T1처리 구의 조사료 섭취량은 높고 배합사료의 섭취량이 낮았는데, 이는cellulose 함량이 높은 조사료의 섭취가 사료섭취량을 감 소시키고 $[3,33]$, 반추위 내 체류시간이 길어짐에 따라 사료 소 화율이 낮아진 결과[8]라고 판단된다. 비육기 T2 처리구의 일 당증체량 및 사료효율이 개선된 결과를 나타낸 것은 비육기에 충분한 에너지 공급이 증체를 향상시킨 것으로 판단되고 $[15,28,29]$, 상대적으로 대조구의 높은 체중에 따른 유지에너지 의 증가가 사료요구율을 높인 것으로 판단된다. 하지만, $\mathrm{T} 1$ 처리구의 사료요구율은 향상된 결과를 보였지만, 일당증체량 은 낮았는데 이는 비육기 증체는 총에너지 섭취량에 의해 결

Table 3. Growth performance of Hanwoo steers receiving different roughage

\begin{tabular}{lccc}
\hline Items & Control & $\mathrm{T} 1$ & $\mathrm{~T} 2$ \\
\hline Initial BW ${ }^{1)}(\mathrm{kg})$ & $125.5 \pm 28.4^{3)}$ & $128.3 \pm 31.5$ & $128.3 \pm 23.3$ \\
Final BW $(\mathrm{kg})$ & $697.4 \pm 50.4$ & $614.6 \pm 48.5$ & $706.7 \pm 98.0$ \\
$\mathrm{ADG}^{2)}(\mathrm{kg} / \mathrm{d})$ & & & $0.52 \pm 0.15$ \\
Growing period & $0.75 \pm 0.13$ & $0.47 \pm 0.11$ & $0.87 \pm 0.13$ \\
Early-fattening period & $0.89 \pm 0.11$ & $0.69 \pm 0.16$ & $0.83 \pm 0.20$ \\
Mid-fattening period & $0.86 \pm 0.10$ & $0.73 \pm 0.17$ & $0.65 \pm 0.17$ \\
Late-fattening period & $0.59 \pm 0.13$ & $0.61 \pm 0.09$ & $0.71 \pm 0.04$ \\
Total Average & $0.70 \pm 0.03$ & $0.60 \pm 0.03$ & \\
\hline
\end{tabular}

\footnotetext{
${ }^{1)} \mathrm{BW}$ : body weight.
}

${ }^{2)}$ ADG: average daily gain.

${ }^{3)}$ Means \pm standard error of mean. 
Table 4. Feed intake and feed conversion ratio of Hanwoo steers receiving different roughage

\begin{tabular}{|c|c|c|c|}
\hline Items & Control & $\mathrm{T} 1$ & $\mathrm{~T} 2$ \\
\hline \multicolumn{4}{|l|}{ Feed intake $(\mathrm{kg})$} \\
\hline \multicolumn{4}{|l|}{ Growing period } \\
\hline Concentrate & $2.69 \pm 0.60^{1)}$ & $2.53 \pm 0.45$ & $2.58 \pm 0.50$ \\
\hline Roughage & $2.65 \pm 0.44$ & $2.54 \pm 0.38$ & $2.45 \pm 0.42$ \\
\hline $\mathrm{DMI}^{3}$ & $4.70 \pm 0.90$ & $4.46 \pm 0.71$ & $4.43 \pm 0.78$ \\
\hline \multicolumn{4}{|l|}{ Early-fattening period } \\
\hline Concentrate & $3.57 \pm 1.27$ & $3.21 \pm 0.98$ & $3.34 \pm 1.10$ \\
\hline Roughage & $2.90 \pm 0.47$ & $2.78 \pm 0.44$ & $2.66 \pm 0.44$ \\
\hline DMI & $5.70 \pm 1.48$ & $5.27 \pm 1.22$ & $5.28 \pm 1.29$ \\
\hline \multicolumn{4}{|l|}{ Mid-fattening period } \\
\hline Concentrate & $5.59 \pm 0.00$ & $5.16 \pm 0.04$ & $6.03 \pm 0.41$ \\
\hline Roughage & $3.30 \pm 0.02$ & $3.33 \pm 0.01$ & $3.56 \pm 0.24$ \\
\hline DMI & $7.83 \pm 0.02$ & $7.47 \pm 0.04$ & $8.44 \pm 0.57$ \\
\hline \multicolumn{4}{|l|}{ Late-fattening period } \\
\hline Concentrate & $8.88 \pm 0.28$ & $7.99 \pm 1.08$ & $8.75 \pm 0.33$ \\
\hline Rice straw & $0.31 \pm 0.66$ & $0.47 \pm 0.48$ & $0.34 \pm 0.63$ \\
\hline DMI & $8.08 \pm 0.45$ & $7.45 \pm 0.83$ & $8.00 \pm 0.57$ \\
\hline \multicolumn{4}{|l|}{ Feed conversion ratio } \\
\hline Growing period & 6.28 & 9.44 & 8.48 \\
\hline Early-fattening period & 6.38 & 7.64 & 6.03 \\
\hline Mid-fattening period & 9.06 & 10.20 & 10.13 \\
\hline Late-fattening period & 15.10 & 12.20 & 13.50 \\
\hline Total average & 10.90 & 12.10 & 10.60 \\
\hline
\end{tabular}

${ }^{1)}$ Means \pm standard error of mean.

정되는데[25] 배합사료 섭취량이 다른 처리구에 비해 낮았고, 보상급여가 이루어지지 않으면 증체가 낮다[7]는 연구보고와 일치하였다.

\section{도체 및 육질 특성}

한우 거세우에 대한 급여 조사료의 종류별 도체특성을 알아 보기 위하여 각 처리구별 7 두씩 시험 도축을 실시하고 도체성
적을 분석한 결과는 Table 5와 같다. 육량특성에서 각 처리구 별 도체중은 각각 $417.0,365.2$ 및 $428.9 \mathrm{~kg}$ 으로 T2처리구가 T1 처리구 보다 유의적으로 높았다 $(p<0.05)$. 처리구별 등지방두 께 및 등심단면적은 각각 $13.6,8.8,13.1 \mathrm{~mm}$ 와 84.9, 77.2 및 $79.1 \mathrm{~cm}^{2}$ 로 유의적인 차이는 없었지만 $\mathrm{T} 1$ 처리구가 비교적 낮 은 경향을 보였다. 육량지수 및 육량 $\mathrm{A}$ 등급 출현율은 $\mathrm{T} 1$ 처리 구가 각각 67.2 와 $43.0 \%$ 로 다른 처리구에 비해 향상된 결과를

Table 5. Carcass characteristics of Hanwoo steers receiving different roughage

\begin{tabular}{|c|c|c|c|}
\hline Items & Control & $\mathrm{T} 1$ & $\mathrm{~T} 2$ \\
\hline \multicolumn{4}{|l|}{ Yield traits } \\
\hline Carcass weight (kg) & $417.0 \pm 16.4^{\mathrm{ab}}$ & $365.2 \pm 14.8^{\mathrm{b}}$ & $428.9 \pm 24.3^{\mathrm{a}}$ \\
\hline Back fat thickness (mm) & $13.6 \pm 2.1^{1)}$ & $8.8 \pm 1.2$ & $13.1 \pm 1.9$ \\
\hline Rib eye area $\left(\mathrm{cm}^{2}\right)$ & $84.9 \pm 4.7$ & $77.2 \pm 3.8$ & $79.1 \pm 2.9$ \\
\hline Yield index & $64.0 \pm 1.4$ & $67.2 \pm 0.9$ & $63.2 \pm 1.5$ \\
\hline Yield grade (A:B:C, \%) & $0: 71: 29$ & 43:57:0 & $29: 42: 29$ \\
\hline \multicolumn{4}{|l|}{ Quality traits } \\
\hline Marbling score & $5.6 \pm 1.0$ & $3.6 \pm 0.5$ & $4.9 \pm 0.6$ \\
\hline Meat color & $5.0 \pm 0.0^{\mathrm{ab}}$ & $5.2 \pm 0.2^{\mathrm{a}}$ & $4.7 \pm 0.2^{\mathrm{b}}$ \\
\hline Fat color & $3.0 \pm 0.0$ & $3.0 \pm 0.0$ & $3.0 \pm 0.0$ \\
\hline Texture & $1.3 \pm 0.2$ & $1.4 \pm 0.2$ & $1.3 \pm 0.2$ \\
\hline Maturity & $2.7 \pm 0.2^{\mathrm{ab}}$ & $3.0 \pm 0.0^{\mathrm{a}}$ & $2.3 \pm 0.2^{\mathrm{b}}$ \\
\hline Quality grade $\left(1^{++}: 1^{+}: 1: 2, \%\right)$ & $29: 13: 29: 29$ & $0: 0: 57: 43$ & $0: 42: 29: 29$ \\
\hline
\end{tabular}

\footnotetext{
${ }^{1)}$ Means \pm standard error of mean.
}

${ }^{a, b}$ Means with different superscripts in the same row differ significantly $(p<0.05)$. 
보였다. 육질특성에서 지방색 및 조직감은 처리구간 차이가 없었지만, 육색 및 성숙도에서는 각각의 처리구별로 5.0, 5.2 및 4.7과 2.7, 3.0 및 2.3으로 나타나 T1처리구가 T2처리구 보다 유의적으로 높았다 $(p<0.05)$. 근내지방도는 육질등급 판정의 중요 요인으로 처리구별로 각각 5.6, 3.6 및 4.9로 갈대를 급여 한 $\mathrm{T} 1$ 처리구가 가장 낮았으나 처리간 통계적인 유의 차이는 인정되지 않았다. 육질등급출현율 $\left(1^{++}: 1^{+}: 1: 2, \%\right)$ 은 각각 29:13:29:29, 0:0:57:43 및 0:42:29:29로 대조구에서 향상된 결과 를 나타내었다. 등심육의 일반조성분을 분석한 결과는 Table 6에서 보는 바와 같이 수분, 조지방, 조단백질 및 조회분에 있어 처리구간 유의적인 차이는 없었다. 육색 CIE L, a, b (명 도, 적색도, 황색도)에 대한 유의적인 차이는 없었지만, 대조구 가 처리구들에 비해 대체적으로 낮았다. 등심육의 지방산 조 성을 분석한 결과(Table 7) Oleic acid는 대조구에서 유의적으 로 높았고, Palmitic acid는 낮았다( $p<0.05)$. 또한 포화지방산 함량은 대조구와 $\mathrm{T} 2$ 처리구가 $\mathrm{T} 1$ 처리구에 비해 낮았고, 불포 화지방산 함량은 높았다( $p<0.05)$.

본 연구의 결과에서 처리구간 육량 및 육질 등급에 있어
차이를 나타낸 것은 출하시 체중의 차이에 따른 결과라 판단 된다. Danner 등[14]은 가축의 육량 및 육질에 영향을 주는 요인으로 나이, 성별 및 체중이라 하였는바, 본 연구의 결과에 서도 $\mathrm{T} 1$ 처리구의 출하체중이 다른 처리구에 비해 낮았기 때문 에 육량 및 육질 등급에서 차이가 나타난 것으로 판단된다. 특히 근내지방도와 육량지수에 있어 처리구간 차이가 컸는데, 비육우의 축적 지방량은 총 에너지 섭취량과 정의 상관관계가 있다고 알려져 있다[5,17]. 백 등[4]과 김 등[21]은 육성기에 목 건초와 볏짚을 급여한 비육우의 근내지방도 및 육질 등급에서 큰 차이가 나타나지 않았다고 하였는데, 본 연구의 결과 육질 등급에서 대조구가 T2 처리구 보다 조금 높은 경향을 나타내 었지만 평균 육질등급 출현율에 있어서는 유의적인 차이를 보이지 않았다. 등심육의 일반조성분에 있어 대조구가 수분함 량이 가장 높고 조지방 함량은 가장 낮았는데, 이전의 연구에 서 수분과 지방함량 간에는 역의 상관관계가 있다는 보고와 일치하였다[19,23]. 육색에서 유의적인 차이는 없었지만 대조 구의 명도(CIE L)가 다른 처리구 보다 낮은 경향을 나타내었는 데, 육질 및 근내지방도는 명도와 정의 상관관계[9]라는 연구

Table 6. Physico-chemical characteristics of the longissimus muscle in Hanwoo steers receiving different roughage

\begin{tabular}{lccc}
\hline Items & Con & T1 & T2 \\
\hline Moisture (\%) & $63.59 \pm 0.17^{1)}$ & $62.86 \pm 1.79$ & $61.36 \pm 2.08$ \\
Crude Fat (\%) & $13.59 \pm 0.29$ & $14.55 \pm 2.15$ & $16.22 \pm 2.72$ \\
Crude Protein (\%) & $20.76 \pm 0.31$ & $20.59 \pm 0.34$ & $20.52 \pm 0.81$ \\
Crude Ash (\%) & $0.82 \pm 0.05$ & $0.78 \pm 0.06$ & $0.76 \pm 0.02$ \\
CIE L & $36.03 \pm 1.15$ & $39.20 \pm 1.20$ & $39.23 \pm 1.82$ \\
CIE a & $19.73 \pm 1.55$ & $21.09 \pm 0.84$ & $21.05 \pm 1.26$ \\
CIE b & $7.85 \pm 0.92$ & $8.36 \pm 0.20$ & $8.16 \pm 0.73$ \\
\hline
\end{tabular}

${ }^{1)}$ Means \pm standard error of mean.

Table 7. Fatty acid composition of the longissimus muscle in Hanwoo steers receiving different roughage

\begin{tabular}{lccc}
\hline Items & Control & $\mathrm{T} 1$ & $\mathrm{~T} 2$ \\
\hline Myristic acid (C14:0) & $3.74 \pm 0.06^{1)}$ & $3.91 \pm 0.36$ & $3.83 \pm 0.26$ \\
Palmitic acid (C16:0) & $28.38 \pm 0.28^{\mathrm{b}}$ & $30.20 \pm 0.56^{\mathrm{a}}$ & $28.89 \pm 0.22^{\mathrm{ab}}$ \\
Palmitoleic acid (C16:ln7) & $5.81 \pm 0.54$ & $5.74 \pm 0.33$ & $5.90 \pm 0.42$ \\
Stearic acid (C18:0) & $10.37 \pm 0.51$ & $10.62 \pm 0.52$ & $9.77 \pm 0.60$ \\
Oleic acid (C18:In9) & $48.20 \pm 0.34^{\mathrm{a}}$ & $46.23 \pm 0.76^{\mathrm{b}}$ & $47.98 \pm 0.36^{\mathrm{ab}}$ \\
Vaccenic acid (C18:ln7) & $0.58 \pm 0.04$ & $0.52 \pm 0.08$ & $0.74 \pm 0.14$ \\
Linoleic acid (C18:2n6) & $2.14 \pm 0.27$ & $2.12 \pm 0.24$ & $2.18 \pm 0.06$ \\
8-Linoleic acid (C18:3n6) & $0.04 \pm 0.01$ & $0.04 \pm 0.01$ & $0.04 \pm 0.01$ \\
Linolenic acid (C18:3n3) & $0.08 \pm 0.01$ & $0.06 \pm 0.01$ & $0.07 \pm 0.01$ \\
Eicosenoic acid (C20:ln9) & $0.39 \pm 0.03$ & $0.35 \pm 0.01$ & $0.42 \pm 0.02$ \\
Arachidonic acid (C20:4n6) & $0.26 \pm 0.01$ & $0.21 \pm 0.01$ & $0.18 \pm 0.07$ \\
\hline Saturated fatty acids & $42.48 \pm 0.69^{\mathrm{b}}$ & $44.74 \pm 0.32^{\mathrm{a}}$ & $42.49 \pm 0.49^{\mathrm{b}}$ \\
Unsaturated fatty acids & $57.52 \pm 0.69^{\mathrm{a}}$ & $55.26 \pm 0.32^{\mathrm{b}}$ & $57.51 \pm 0.49^{\mathrm{ab}}$ \\
Monounsaturated fatty acid & $54.98 \pm 0.77$ & $52.84 \pm 0.49$ & $55.03 \pm 0.56$ \\
Polyunsaturated fatty acids & $2.53 \pm 0.29$ & $2.42 \pm 0.25$ & $2.47 \pm 0.07$ \\
\hline
\end{tabular}

\footnotetext{
${ }^{1)}$ Means \pm standard error of mean.

${ }^{a, b}$ Means with different superscripts in the same row differ significantly $(\not<0.05)$.
} 
보고와는 상반된 결과를 보였다. 대조구 및 $\mathrm{T} 2$ 처리구에서 불 포화지방산 함량은 높고 포화지방산 함량은 낮게 분석되었는 데, 쇠고기의 지방성분은 맛에 관여하는 요인으로 알려져 있 고[6], 특히 oleic acid는 단일불포화지방산으로서 쇠고기를 비 롯한 식육의 주요 지방산으로 풍미에 영향을 주는 것으로 알 려져 있다[1].

\section{References}

1. Anderson, D. A., Kisellan, J. A. and Watt, B. K. 1975. Comprehensive evaluation of fatty acid in beefs. J. Am Diet Assoc. 67, 35-41.

2. A.O.A.C. 1995. Official method of analysis. 16th ed. Association of Official Analytical Chemists. Washington, DC. USA.

3. Balch, C. C. and Campling, R. C. 1962. Regulation of voluntary intake in ruminants. Nutr. Abstr. Rev. 32, 669.

4. Back, B. H. 1994. Annual Report of Extension Service (Animal Sci.). Rural Development Administration (RDA)

5. Berg, R. T., Anderson, B. B. and Liboriussen, T. 1978. Growth of bovine tissue 1. Genetic influence on growth patterns of muscle, fat and bone in young bulls. Anim Prod 26, 245-258.

6. Blumer, T. N. 1963. Relationship of marbling to the palatability of beef. J. Anim Sci. 22, 771-778.

7. Butterfield, R. M. and May, N. D. S. 1966. Muscle of the ox. University of Queensland. Press. Brisbane, Australia.

8. Campling, R. C., Freer, M. and Balch, C. C. 1961. Factors affecting the voluntary intake of food by cows. II. The relationship between the voluntary intake of roughages, the amount of digesta in the reticulo-rumen and the rate of disappearance of digesta from the alimentary tract. Brit. J. Nutr. $15,531-540$

9. Cho, S. H., Kim, J. H., Seong, P. N., Cho, Y. M., Chung, W. T., Park, B. Y., Chung, M. O., Kim, D. H., Lee, J. M. and Ahn, C. N. 2008. Physcio-chemical meat quality properties and nutritionally composition of Hanwoo steer beef with $1^{++}$quality grade. Korean J. Food Sci. Ani. Resour. 28, 333-343.

10. Choi, J. H., Kim, J. H., Lee, J. S., Han, Y. S. and Han, S. S. 1997. Effect of reed root extract (RRE) on learning and memory impairment animal model SAMP8. I . Feeding effect of RRE on lipid metabolism of SAMP8. Kor. J. Geron. 7, 17-22.

11. Chun, W. B., Yoon, C., Lee, J. M. and Park, J. M. 1983. Studies on the productivity of the native reed (Phragmites communis Trinius) 1. Changes in the productivity of the native reed (Phragmites communis Trinius) during the period of vegetation. J. Kor. Grassl. Sci. 4, 89-97.

12. Chun, W. B., Yoon, C. and Rho, S. H. 1986. Studies on the productivity of the native reed (Phragmites communis Trinius). 2. Effect of fertilizer application on the productivity of the native reed during the period of vegetation. J. Kor. Grassl. Sci. 6, 24-30.
13. Chun, W. B., Yoon, C. and Son, M. H. 1986. Studies on the productivity of the native reed (Phragmites communis Trinius). 3. Effect of cutting time on the regrowth and feed composition of native reed. J. Kor. Grassl. Sci. 6, 78-83.

14. Danner, M. L., Fox, D. G. and Black, J. R. 1980. Effect of feeding system on performance and carcass characteristics of yearling steers, steer calves and heifer calves. J. Anim Sci. 50, 394-404.

15. Drori, D., Levy, D., Folman, Y. and Holzer, Z. 1974. Compensatory growth of intensively raised bull calves $\Pi$. The effect of feed energy concentration. J. Anim Sci. 38, 654-661.

16. Folch, J., Lees, M. and Stanley, G. H. S. 1957. A simple method for the isolation and purification of total lipids from animal tissues. J. Bio. Chem 226, 497-500.

17. Fortin, A., Reid, J. T., Magia, A. M., Sim, D. W. and Wellington, G. H. 1980. Effect of energy intake level and influence of breed and sex on the physical composition of the carcass of cattle. J. Anim Sci. 51, 331-339.

18. Hwang, I. K. and Ahn, S. Y. 1975. Studies on of the Anthocyanins in wild vines (Vitis amurensis ruprecht) (part 2). J. Kor. Agri. Chem Soc. 18, 188-193.

19. Jacobs, J. A., Miller, J. C., Sauters, E. A., Howes, A. D., Araji, A. A., Gregory, T. L. and Hust, C. E. 1977. Bulls versus steers. II. Palatability and retail acceptance. J. Anim Sci. 46, 699-702.

20. Kang, H. K. and Chang, N. K. 1985. Annual net production and the stability of the pure Phragmites communis grassland in the lower course of Nakdong river. J. Kor. Grassl. Sci. $5,8-12$.

21. Kim, I. S., Jung, K. K., Kim, J. Y., Lee, S. W., Back, K. H. and Choi, C. B. 2007. Effect of feeding high quality hay on performance and physic-chemical characteristics of carcass of Hanwoo steers. J. Anim Sci. Technol. 49, 783-800.

22. Kim, S. Y., Sung, K. I. and Kim, B. W. 2010. Plant height, dry matter yield and forage quality at different maturity of reed. Grassl. Forage Sci. Proc. 146-147.

23. Landon, M. E., Hedrick, H. B. and Thompson, G. B. 1978. Live animal performance and carcass characteristics of beef bullocks and steers. J. Anim Sci. 47, 151-155

24. Mader, T. L. and Horn, G. W. 1986. Low-quality roughages for steers grazing wheat pasture. II. Effect of wheat forage intake and utilization. J. Anim Sci. 62, 1113-1119.

25. Martin, T. G., Perry, T. W., Mohler, M. T. and Owens, F. H. 1979. Comparison of four levels of protein supplementation with and without oral diethylstilbestrol on daily gain, feed conversion and carcass traits of bulls. J. Anim Sci. 48, 1026-1932.

26. MIFAFF. 2010. Forage production of Animal Science. Ministry for Food, Agriculture, Forest and Fisheries.

27. Morrison, W. R. and Smith, L. M. 1964. Preparation of fatty acid methylesters and dimethylacetals from lipid with boron fluoridemethanol. J. Lipid Resour. 5, 600-608.

28. Myer, J. H., Hull, J. L., Weitkamp, W. H. and Bomilla, S. 1965. Compensatory growth responses of fattening steers following various low energy intake regimes on hay or in- 
rigated pasture. J. Anim Sci. 24, 29-37.

29. Sainz, R. D., Torre, F. D. and Oltjen, J. W. 1995. Compensatory growth and carcass quality in growth-restricted and refed beef steers. J. Anim Sci. 73, 2971-2979

30. Shin, K. Y., Lee, G. H., Park, C. H., Kim, H. J., Park, S. H., Kim, S., Kim, H. S., Lee, K. S., Won, B. Y., Lee, H. G., Choi, J. H. and Suh, Y. H. 2007. A novel compound, maltolyl p-coumarate, attenuates cognitive deficits and shows neuroprotective effects in vitro and in vivo dementia models. J. Neurosci. Res. 85, 2500-2511.

31. Seo, S., Han, D. D., Jang, S. S., Kim, W. H., Jung, M. W., Choi, J. H., Kim, S., Kim, H. Y. and Lee, J. K. 2012. Utilization Survey and Forage Quality of Phragmites communis and Native Grasses in Haenam, Pyeongchang and
Wonju Regions, 2010. J. Kor. Grassl. Forage Sci. 32, 1-8. 32. Seo, S., Kim, W. H., Jung, M. W., Park, H. S., Shim, J. J., Park, J. G., Sung, H. G., Kim, J. D. and Lee, J. K. 2011. Studies on Utilization Survey and Forage Quality of Phragmites communis and Miscanthus sinensis as Native Grasses in Paju and Ansan District, 2010. J. Kor. Grassl. Forage Sci. 31, 151-158.

33. Van Soest, P. J. 1965. Symposium on factors influencing the voluntary intake of herbage by ruminants: Voluntary intake in relation to chemical composition and digestibility. $J$. Anim Sci. 23, 834-844.

34. White, T. W. and Reynolds, W. L. 1969. Various sources and levels of roughage in steer rations. J. Anim Sci. 29, 705-710.

\section{초록 : 갈대 급여가 한우 거세우의 발육, 도체 및 육질특성에 미치는 영향}

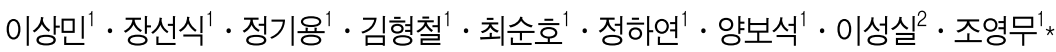

('농촌진흥청 국립축산과학원, ${ }^{2}$ 경상대학교 응용생명과학부)

본 연구는 한우 거세우의 비육시 급여 조사료의 종류가 발육 및 도체특성에 미치는 영향을 구명하고자 수행하 였다. 한우 거세우 21 두를 3 처리(건초, 갈대 및 갈대+볏짚), 처리당 7 두씩 완전 임의 배치하였다. 시험결과 개시체 중 및 종료체중은 처리구별(대조, T1 및 T2)로 각각 $125.5,128.3$ 및 $128.3 \mathrm{~kg}$ 과 697.4, 614.6 및 $706.7 \mathrm{~kg}$ 으로 나타 났다. 일당증체량은 대조구 $(0.70 \mathrm{~kg} / \mathrm{d})$ 와 T2 처리구 $(0.71 \mathrm{~kg} / \mathrm{d})$ 가 T1 처리구 $(0.60 \mathrm{~kg} / \mathrm{d})$ 보다 향상된 경향을 나타 났지만 유의적인 차이는 없었다. 건물섭취량은 유의적인 차이는 없었지만 $\mathrm{T} 1$ 처리구가 다른 처리구에 비해 비교 적 낮았다. 육량특성에서 도체중은 대조구와 $\mathrm{T} 2$ 처리구간에는 차이가 없었지만, T2처리구는 T1 처리구에 비해 높 았다( $p<0.05)$. 등지방두께와 등심단면적은 대조구와 T2처리구가 T1처리구 보다 높았고, 육량등급(A:B:C, \%)은 T1 처리구(43:57:0)가 다른 처리구(대조구 0:71:29, T2 29:42:29)에 비해 높았다. 육질특성에서는 지방색과 조직감은 처 리구 간 유의적인 차이가 없었다. 그러나 육색과 성숙도는 $\mathrm{T} 2$ 처리구에 비해 $\mathrm{T} 1$ 처리구가 유의적으로 높았다 ( $p<0.05)$. 근내지방도 및 육질1등급이상 출현율은 $\mathrm{T} 1$ 처리구에 비해 대조구와 $\mathrm{T} 2$ 처리구가 높았다. 본 연구의 결과 를 종합해 볼 때 거세한우 비육시 조사료로서 갈대와 볏짚을 혼합급여할 때 발육, 사료 이용성 및 도체 성적이 향상되어 갈대가 한우의 조사료원으로서 활용가치가 있는 것으로 판단되었다. 